\title{
ВІБРАЦІЙНЕ МАНІПУЛЮВАННЯ ВИРОБАМИ
}

\author{
Петро Коруняк $^{1}$, к .т. н., Іван Керницький ${ }^{1}$, д. т. н., Сергій Баранович ${ }^{1}$, к. т. н., \\ Іван Малик ${ }^{2}$ Роман Беспалов ${ }^{1}$ \\ ${ }^{1}$ Львівський наиіональний аграрний університет, \\ вул. Володимира Великого, 1, м. Дубляни, Львівський район, Львівська обл., Украйна, \\ e-mail:petrokoruniak@gmail.com,ivankernytskyy@ukr.net, baranovich1977@ukr.net \\ ${ }^{2}$ Чернівеиький коледж Львівського національного аграрного університету, \\ вул. Олекси Доброго, 4, м. Чернівиі, Украӥна, \\ e-mail:fifka5@ukr.net
}

https://doi.org/10.31734/agroengineering2021.25.063

Коруняк П., Керницький І., Баранович С., Малик І., Беспалов Р. Вібраційне маніпулювання виробами Основою розвитку машинобудування $\epsilon$ підвищення ефективності виробництва, збільшення випуску продукції $\mathrm{i}$ підвищення іï якості за одночасного зниження трудових витрат, поліпшення організації та управління виробництвом. Це забезпечується вдосконаленням існуючих і впровадженням нових видів устаткування, технологічних процесів і засобів їх механізації та автоматизації. Вдосконалення засобів автоматизації здійснюється як створенням засобів автоматизації існуючого устаткування з метою підвищення його ефективності, так і створенням нових технологічних комплексів, де пов'язані питання підвищення продуктивності, надійності, рівня автоматизації, якості продукції тощо.

Найбільш трудомісткими 3 погляду автоматизації вважаються процеси, які пов'язані з необхідним орієнтуванням виробів під час, наприклад, оброблення, складання, контролю, пакування тощо. Для його реалізації найефективнішим $\epsilon$ вібраційне устаткування, завдяки якому здійснюється орієнтування виробів у необхідне положення та переміщення їх на робочу позицію або в технологічне обладнання.

Важливого значення, 3 погляду підвищення ефективності роботи існуючих систем під час спряження деталей, а також позиціонування їх у взаємодії з маніпуляторами набуває застосування у виробничих процесах специфічних вібраційних транспортувальних пристроїв. Їх суттєвою особливістю $є$ те, що переміщення виробу здійснюється не в результаті сумісного руху з робочим органом, а внаслідок вібрації останнього. Ця обставина визначає низку важливих технологічних та експлуатаційних переваг. Використання електромагнітного приводу в таких пристроях дає змогу реалізувати необхідність частого майже миттєвого безінерційного їх урухомлення (увімкнення $\mathrm{i}$ вимкнення), а також плавне регулювання швидкості та зміни напрямку руху.

Пристрої створені за структурною схемою транспортерів з незалежним багатокомпонентним збуренням коливань та електромагнітним приводом у дво-, три- і багатомасових коливальних системах з комбінованими пружними системами, що робить їх універсальними, уможливлює реалізацію різних режимів вібротранспортування, дистанційного або програмного керування роботою тощо.

Ключові слова: вібрація, конвеєр, виріб, транспортування, коливання, робочий орган, модуль, маніпулювання.

Koruniak P., Kernytskyi I., Baranovych S., Malyk I., Bespalov R. Manipulation of products by vibration transport modules

The basis for the development of mechanical engineering is to improve production efficiency, increase production and raise its quality while reducing labor costs, to improve organization and management of production. This is ensured by the improvement of the existing and introduction of new types of equipment, technological processes and means of their mechanization and automation. Improvement of automation means is carried out both by creating means of automation of the existing equipment for the purpose of its efficiency increase, and creation of new technological complexes where questions of increase of productivity, reliability, level of automation, quality of production, etc. are connected.

In terms of automation, the most labor-intensive processes involve the necessary orientation of products during processing, assembly, control, packaging, etc. For its implementation the most effective is the vibrating equipment thanks to which orientation of products is in the necessary position and its movement on a working position or in the technological equipment is carried out.

It is important in order to increase the efficiency of work of the existing systems during conjugation of details, and also their positioning in interaction with manipulators acquires application in production processes of specific vibrating transport devices. Their essential feature is that the product is moved not as a result of joint movement with the working body, but due to the vibration of the latter. This fact determines a number of important technological and operational advantages. The use of electromagnetic actuators in such devices secures satisfaction of the need for frequent almost instantaneous inertial movement (on and off), as well as smooth speed control and change of direction. 
Devices are created according to the structural scheme of conveyors with independent multicomponent oscillation and electromagnetic drive in two-, three- and multi-mass oscillating systems with combined elastic systems makes them universal, allows to implement different modes of vibrotransportation, remote or software control, etc.

Key words: vibration, conveyor, product, transportation, oscillations, working body, module, manipulation.

Постановка проблеми. Зі всієї сукупності технологічних процесів найбільш трудомісткими 3 погляду автоматизації вважаються процеси, які пов'язані з необхідним орієнтуванням виробів під час, наприклад, оброблення, складання, контролю, пакування тощо. Тому важливою складовою як комплексної механізації, так і автоматизації виробництва є процеси просторового маніпулювання об'єктами оброблення та складання [12]. Оскільки маніпуляція є процесом складних видів дій, то стосовно виробничих процесів під автоматичним маніпулюванням виробами слід розуміти комплекс обов'язкових прийомів, які необхідно виконати $з$ ними під час автоматизації будь-якої технологічної операції.

Розглядаючи маніпулювання як здійснення окремих рухів виробами, його можна поділити на вже відомі етапи: розгону, встановленого руху i гальмування. Реалізація їх супроводжується виникненням динамічних навантажень, які, своєю чергою, можуть призвести до порушення точності позиціонування виробу, функціонування технологічного обладнання, а також, зокрема, під час сумісної роботи з промисловими роботами. 3 огляду на це одним із напрямів підвищення ефективності таких виробничих процесів $є$ застосування специфічних транспортувальних вібраційних пристроїв, які дають змогу змінювати не лише напрямок, а й вид руху об'єкта маніпулювання (транспортування).

Їхньою суттєвою особливістю $\epsilon$ те, що переміщення виробу здійснюється не в результаті сумісного руху з робочим органом, а внаслідок вібрації останнього. Ця обставина визначає низку важливих технологічних та експлуатаційних переваг. Використання електромагнітних приводів у таких пристроях дає змогу реалізувати необхідність частого майже миттєвого безінерційного їх урухомлення (увімкнення і вимкнення), а також плавне регулювання швидкості руху.

Аналіз останніх досліджень і публікацій. Першими такими моделями можна вважати вібротранспортери 3 електромагнітним приводом та еліптичними коливаннями, дослідження яких започаткувало створення низки вібраційних реверсивних транспортерів (ВТМ), або транспортувальних модулів, і вібраційних транспортноманіпулювальних модулів (ВТММ) [2; 3; 13; 17; $18]$.
Пристрої створені за структурною схемою транспортерів із незалежним багатокомпонентним збуренням коливань та електромагнітним приводом у дво-, три- і багатомасових коливальних системах 3 комбінованими пружними системами, що робить їх універсальними, уможливлює реалізацію різних режимів вібротранспортування, дистанційного або програмного керування роботою тощо [1; 4; 7-10; 18].

Використання вібраційних транспортувальних модулів і транспортно-маніпулювальних модулів значно спрощує сучасні способи й засоби автоматичного маніпулювання виробами $[5 ; 6]$. Їх легко можна вмонтовувати в комплекси автоматизованого і механізованого обладнання та гнучкі виробничі системи, замінюючи в цьому разі складні системи позиціонування, маніпулятори та роботи $[15 ; 16]$.

Під час маніпулювання виробами на вібруючій площині (рис. 1) можна реалізувати різноманітні траєкторії їхнього руху в прямому i зворотному (реверс) напрямках та обертання виробу навколо своєї осі в різні сторони. Значення швидкості транспортування може коливатись у широкому діапазоні. За цих умов забезпечуються незмінне положення і безвідривний плавний рух предметів відносно поверхні робочого органа [11; 14]. Крім того, за необхідності можна передбачити переміщення предметів догори за круговою траєкторією або вертикально.

Слід зауважити, що зазначені пристрої набули найефективнішого застосування у виробничих процесах 3 виробами, які мають незначні масово-геометричні параметри.

Одну з конструкцій ВТММ наведено на рис. 1. Він побудований за тримасною коливальною схемою і об'єднує три коливні маси: $m_{1}, m_{2}$ і $m_{3}$, які з'єднані між собою сталевими пружними системами. Робоча маса $m_{1}$ охоплює транспортувальну поверхню (робочий орган, дека) 1 прямокутної форми, дві пари якорів 2 поздовжніх та поперечних коливань, якір 3 вертикальних коливань, чотири кронштейни 4 для кріплення пружних елементів (пружин) та барабан 5, які складають в сумі жорсткий вузол.

Проміжна маса $m_{2}$ складається з барабана 63 двома парами електромагнітних віброзбурювачів (електромагнітів 3 котушками) 7 поздовжніх та поперечних коливань і чотирьох кронштейнів 8 для закріплення пружин. 

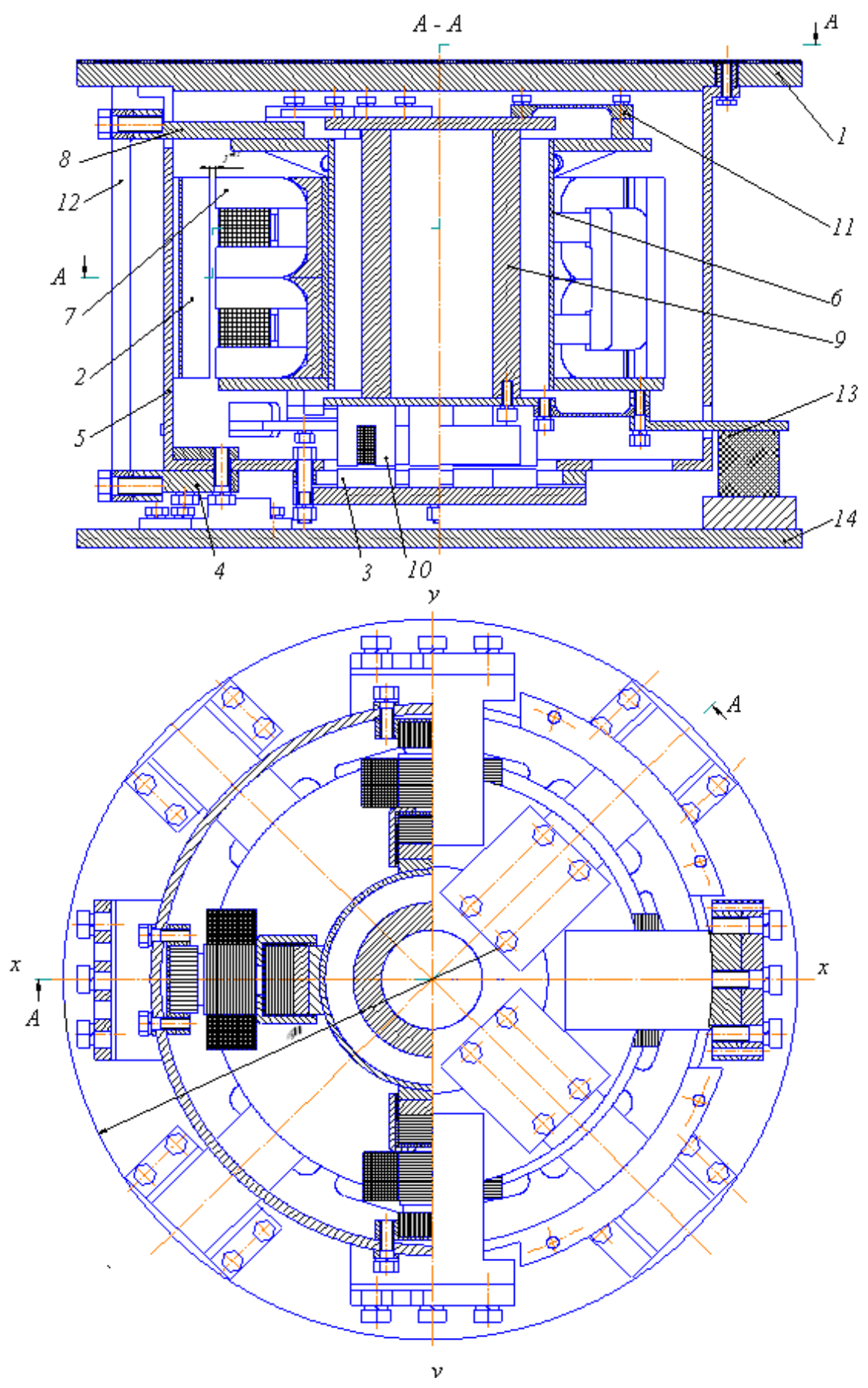

Рис. 1. Конструктивна схема вібраційного транспортно-маніпулювального модуля

Fig. 1. Constructive scheme of the vibrating transport-manipulating module

Реактивна маса $m_{3}$ складається 3 товстостінної труби 9 і закріпленого до неї електромагнітного віброзбурювача вертикальних коливань 10.

Проміжна $m_{2}$ і реактивна $m_{3}$ маси з'єднані між собою за допомогою восьми плоских пружин 11 , розміщених у горизонтальних площинах, по чотири, на торцях мас $m_{2}, m_{3}$. Пружини 11 дозволяють коливання мас у вертикальному напрямку. Робоча $m_{1}$ і проміжна $m_{2}$ маси з'єднані між собою за допомогою чотирьох плоских гратчастих пружин 12, розміщених через $90^{\circ}$ у вертикальній площині, які дозволяють коливання мас у будь-якому напрямку горизонтальної площини. Віброізоляція модуля здійснюється за допомогою чотирьох гумових амортизаторів 13, через які пристрій опирається на нерухому опору 14. 
Пристрій розрахований на робочу частоту коливань 50 Гц, яка забезпечується подачею напруги через однопівперіодні випрямлячі. Під час подачі напруги через випрямляч на віброзбурювач вертикальних коливань 10 за однотактною схемою живлення і пару віброзбурювачів 7 горизонтальних поздовжніх коливань за двотактною схемою живлення (напрямок по $x$ - $x$ ) робочий орган 1 здійснює напрямлені коливання 3 кутом вібрації $\beta$, які забезпечують вібротранспортування деталей у поздовжньому напрямку. Переміщення виробів у поперечному напрямку відбувається аналогічно попередньому випадку за умови увімкнення віброзбурювачів вертикальних та горизонтальних поперечних коливань (напрямок $y$-y).

Із зсувом фаз вертикальних коливань відносно горизонтальних коливань транспортувальна поверхня здійснює коливання за еліптичними траєкторіями, які забезпечують ефективне вібротранспортування зі значно більшими коефіцієнтами швидкості порівняно 3 напрямленими коливаннями, у двох взаємно перпендикулярних напрямках. Одночасне включення горизонтальних поздовжніх та поперечних коливань, а також вертикальних коливань забезпечує транспортування виробів у будь-якому напрямку транспортувальною поверхнею. Напрямок та швидкість транспортування залежать від співвідношення амплітуд поздовжніх і поперечних коливань, а також зсуву фаз між ними. Зміна напрямку (реверс) транспортування здійснюється iз зсувом фаз вертикальних коливань відносно горизонтальних на $180^{\circ}$. Зміна кута зсуву фаз між вертикальною і горизонтальною складовими коливань уможливлює одержання будь-якого нахилу осі еліпса траєкторії коливань і відповідно різних режимів та напрямків вібротранспортування.

Під час відімкнення віброзбурювача вертикальних коливань та ввімкнення обох пар горизонтальних віброзбурювачів за двотактною схемою живлення із зсувом фаз між ними на $90^{\circ}$ кожна точка транспортувальної поверхні здійснюватиме коливання за круговими траєкторіями у горизонтальній площині, що забезпечує обертання деталей навколо своїх осей. Реверсування напрямку обертання здійснюється зміною кута зсуву фаз між поздовжніми і поперечними коливаннями на $180^{\circ}$.

Пружні системи модуля забезпечують коливання тримасної коливальної системи як двох двомасних коливальних систем. У разі горизонтальних коливань маса $m_{3}$ приєднується до маси $m_{2}$ (коливаються як одне ціле) і двома коливальними масами $\epsilon$ маса $m_{1}$ i $\left(m_{2}+m_{3}\right)$, а в разі вертикальних коливань сумуються маси $m_{1}$ i $m_{2}$ i коливальними масами є маси $\left(m_{1}+m_{2}\right)$ i $m_{3}$. Тому під час розрахунку пружної системи зведена маса $\mathrm{m}$ коливальної системи в першому варіанті визначається за формулою

$$
\mathrm{m}=\frac{\mathrm{m}_{1}\left(\mathrm{~m}_{2}+\mathrm{m}_{3}\right)}{\left(\mathrm{m}_{1}+\mathrm{m}_{2}+\mathrm{m}_{3}\right)},
$$

а в другому -

$$
m=\frac{m_{3}\left(m_{1}+m_{2}\right)}{\left(m_{1}+m_{2}+m_{3}\right)} .
$$

Подальший розрахунок аналогічний тому, що викладений у праці [18].

Відомі також інші конструкції ВТММ. Так, у результаті науково-пошукового підходу було запропоновано більш удосконалену конструкцію двомасного ВТММ, основні результати досліджень та їх апробація викладені авторами в працях $[4 ; 7-10 ; 19 ; 20]$.

Постановка завдання. Метою роботи є дослідження, моделювання та реалізація складного руху виробу на горизонтальній вібруючій площині, а також вплив параметрів на характер руху.

Виклад основного матеріалу. Розглянемо рух тіла масою $m$ по горизонтальній поверхні. Поверхня здійснює коливання у вертикальному напрямку згідно із законом $z_{l}(t)$, а також коливання в горизонтальній площині у двох взаємно перпендикулярних напрямках $x_{l}(t), y_{l}(t)$, а саме:

$$
\begin{gathered}
x_{1}(t)=a \sin (\omega t+\alpha) ; \\
y_{1}(t)=b \sin (\omega t+\beta) ; \\
z_{1}(t)=c \sin (\omega t),
\end{gathered}
$$

де $a, b, c$ - амплітуди коливань; $\alpha, \beta$ - різниця фаз; $\omega=2 \pi v=2 \pi 50=314 \mathrm{paz} / \mathrm{c}$.

Рухому систему координат поєднаємо 3 рухомою площиною, причому початок координат збігається з початковим положенням тіла. Тоді рух тіла можна розглядати як складний (рис. 2): поступальний переносний рух разом 3 рухомою поверхнею і відносний рух відносно рухомої системи відліку.

Диференціальні рівняння відносного руху тіла можна записати так:

$$
\begin{gathered}
m \frac{d^{2} x}{d t^{2}}=-m \frac{d^{2} x_{1}}{d t^{2}}+T_{1} ; m \frac{d^{2} y}{d t^{2}}=-m \frac{d^{2} y_{1}}{d t^{2}}+T_{2} ; \\
m \frac{d^{2} z}{d t^{2}}=-m \frac{d^{2} z_{1}}{d t^{2}}+N-m g,
\end{gathered}
$$

де $x(t), y(t), z(t)$ - закон руху точки відносно рухомої системи відліку; $T_{1}, T_{2}-$ проєкції сили тертя; $N$ - нормальна реакція; $g=9,81 \mathrm{~m} / \mathrm{c}-$ прискорення вільного падіння. 


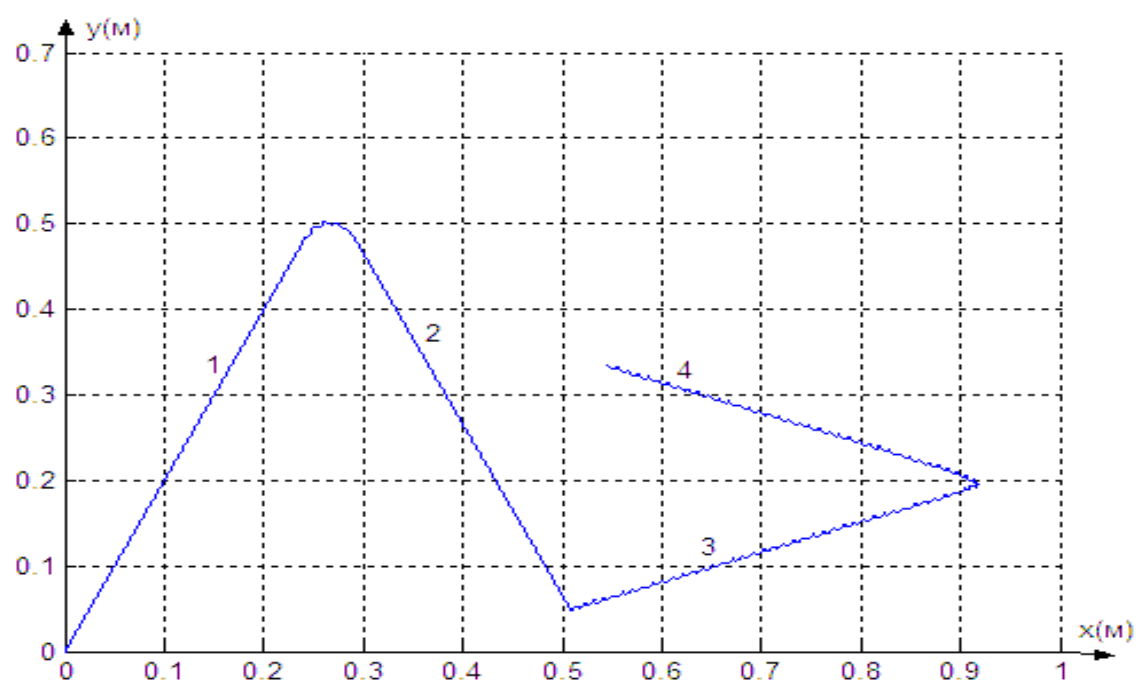

Рис. 2. Траєкторія руху тіла за різних значень зсуву фаз: ділянка $1-\alpha=\pi / 2, \beta=\pi / 2$; ділянка $2-\alpha=\pi / 2, \beta=-\pi / 2$; ділянка $3-\alpha=\pi / 2, \beta=0$; ділянка $4-\alpha=-\pi / 2, \beta=0$; $0<t<3,2 ; a=0,001 \mathrm{M} ; b=0,002 \mathrm{M} ; f=0,5 ; c=0,001 \mathrm{M}$

Fig. 2. The trajectory of the body at different values of the phase shift:

$$
\begin{gathered}
\text { area } 1-\alpha=\pi / 2, \beta=\pi / 2 ; \text { area } 2-\alpha=\pi / 2, \beta=-\pi / 2 ; \\
\quad \text { area } 3-\alpha=\pi / 2, \beta=0 ; \text { area } 4-\alpha=-\pi / 2, \beta=0 ; \\
0<t<3.2 ; a=0.001 \mathrm{~m} ; b=0.002 \mathrm{~m} ; f=0.5 ; c=0.001 \mathrm{~m}
\end{gathered}
$$

Вважаємо, що тіло під час руху не відривається від площини (безвідривний режим), тобто $z(t)=0$. Тоді 3 останнього рівняння системи (4), враховуючи (3), знаходимо нормальну реакцію

$$
N=m g-m \omega^{2} c \sin (\omega t)
$$

Умова безвідривності $N>0 \Rightarrow c<\frac{g}{\omega^{2}}$.

Під час руху сила тертя досягає граничного значення, тобто

$$
|T|=f N=f\left(m g-m \omega^{2} c \sin (\omega t)\right) .
$$

Тоді $T_{1}$ і $T_{2}$ будуть дорівнювати

$$
\begin{gathered}
T_{1}=-m\left(g-\omega^{2} c \sin (\omega t)\right) \frac{\dot{x}}{\sqrt{\dot{x}^{2}+\dot{y}^{2}}} ; \\
T_{2}=-m\left(g-\omega^{2} c \sin (\omega t)\right) \frac{\dot{y}}{\sqrt{\dot{x}^{2}+\dot{y}^{2}}} .
\end{gathered}
$$

3 рис. 3 видно, що при $f>0,1$ коефіцієнт тертя практично не впливає на значення переміщення. Підставивши вирази (3) і (7) у (4), одержимо диференціальні рівняння відносного руху тіла в остаточній формі:

$$
\begin{gathered}
\frac{d^{2} x}{d t^{2}}=a \omega^{2} \sin (\omega t+\alpha)-\left(g-\omega^{2} c \sin (\omega t)\right) \frac{\dot{x}}{\sqrt{\dot{x}^{2}+\dot{y}^{2}}} \\
\frac{d^{2} y}{d t^{2}}=b \omega^{2} \sin (\omega t+\beta)-
\end{gathered}
$$

$$
-\left(g-\omega^{2} c \sin (\omega t)\right) \frac{\dot{y}}{\sqrt{\dot{x}^{2}+\dot{y}^{2}}} .
$$

Ця система рівнянь розв'язувалась числовим методом у середовищі MATLAB за таких початкових умов: $\quad t=0, \quad x=0, \quad y=0$, $\dot{x}=-a \omega \cos (\alpha), \dot{y}=-b \omega \cos (\beta) . \quad$ Результати розв'язку показані на рис. 3-6.

3 рис. 6 можна визначити середню швидкість руху в напрямку координатних осей та сумарну середню швидкість:

$$
\begin{gathered}
V_{x}=0,065 / 0,2=0,325 \mathrm{~m} / \mathrm{c} ; V_{y}=0,042 / 0,2=0,21 \mathrm{~m} / \mathrm{c} ; \\
V_{s}=0,078 / 0,2=0,39 \mathrm{M} / \mathrm{c} .
\end{gathered}
$$

Варто зауважити, що за умови відсутності вертикальних коливань $(c=0)$ і наявності їх лише в горизонтальній площині (у двох взаємно перпендикулярних напрямках) кожна точка робочої поверхні описує коло або еліпс (рис. 7, 8), а тіло, яке міститься на ньому, обертається.

Розглянемо такий приклад. Якщо необхідно перемістити тіло 23 початкового положення $M_{0}\left(x_{20}, y_{20}\right)$ у кінцеве положення $M_{1}\left(x_{2 k}, y_{2 k}\right)$, то можна це зробити різними способами.

1. Спочатку можна переміщати тіло 2 паралельно до осі $O x$, поки $x_{2} \leq x_{2 k}$, а потім переміщати тіло 2 паралельно до осі $O y$, поки $y_{2} \leq y_{2 k}$. Цей рух можна описати диференціальними рівняннями, аналогічними до рівнянь (4). Тому система диференціальних рівнянь у цьому разі матиме вигляд 


$$
\frac{d^{2} z_{2}}{d t^{2}}=\left(F_{2}(t)-c_{z} z_{2}\right) /\left(m_{1}+m_{2}\right)
$$

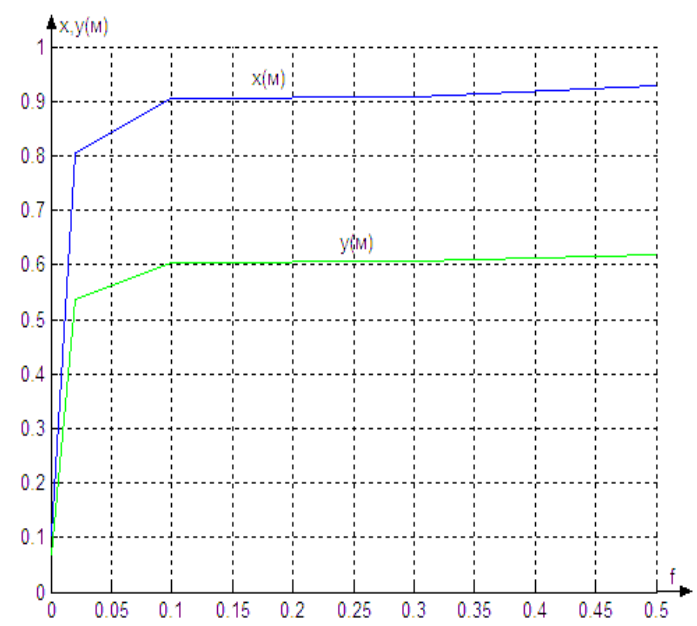

Рис. 3. Залежність значення переміщення тіла від коефіцієнта тертя ковзання: $a=0,0015 ; b=0,001 ; \alpha=\beta=\pi / 2 ; 0<t<2$

Fig. 3. Dependence of the amount of body displacement on the coefficient of sliding friction: $a=0.0015 ; b=0.001 ; \alpha=\beta=\pi / 2 ; 0<t<2$

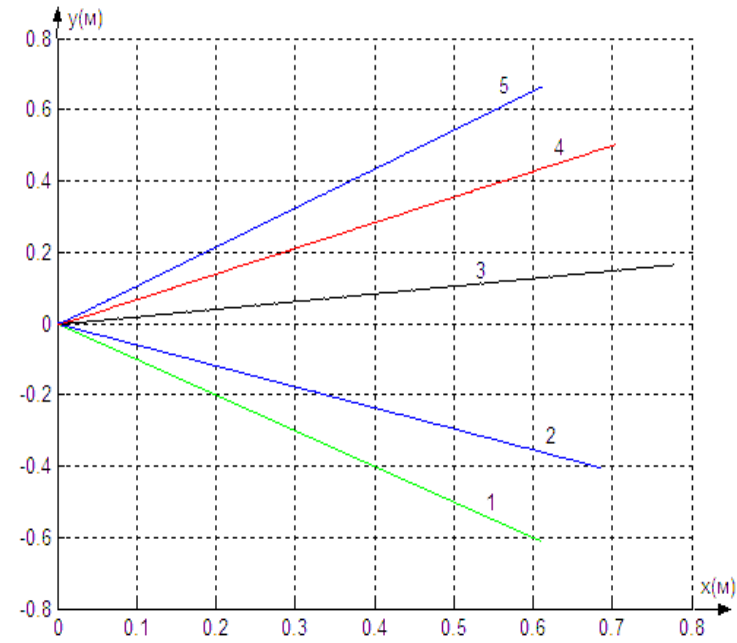

Рис. 5. Залежність напрямку руху тіла від зміни фаз: лінія $1-\beta=-\pi / 2$; лінія $2-\beta=-\pi / 4$; лінія $3-$

$\beta=\pi / 8$; лінія $4-\beta=\pi / 4$; лінія $5-\beta=\pi / 2 ; 0<t<2$; $a=b=0,001 \mathrm{M} ; f=0,3 ; \alpha=\pi / 2$

Fig. 5. Dependence of the direction of body motion on phase change: line $1-\beta=-\pi / 2$; line $2-\beta=-\pi / 4$;

line $3-\beta=\pi / 8$; line $4-\beta=\pi / 4$; line $5-\beta=\pi / 2 ; 0<t<$ $2 ; a=b=0.001 \mathrm{~m} ; f=0.3 ; \alpha=\pi / 2$

$$
N=m_{2} \frac{d^{2} z_{2}}{d t^{2}}+m_{2} g ; \quad T=f N \operatorname{sign}\left(\dot{x}_{2}\right) ;
$$

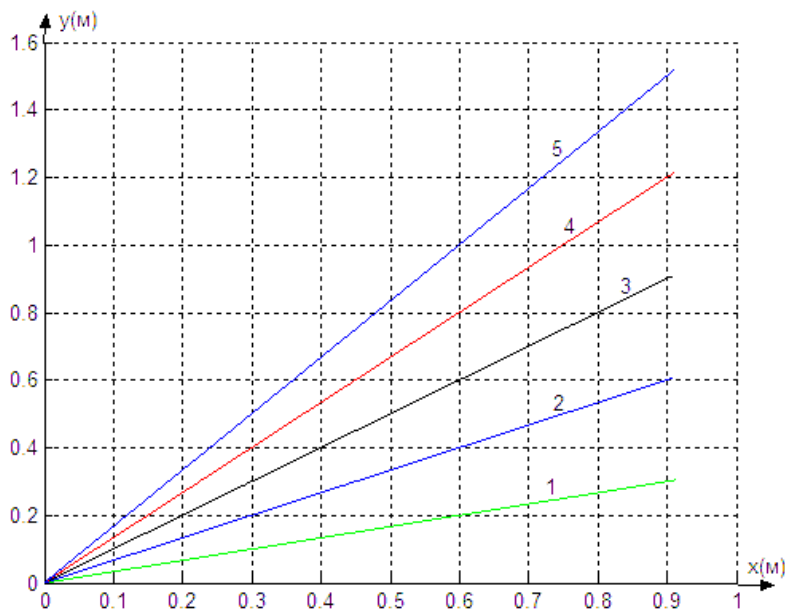

Рис. 4. Залежність напрямку руху тіла від співвідношення амплітуд:

лінія $1-b / a=1 / 3$; лінія $2-b / a=2 / 3$; лінія $3-b / a=1$; лінія $4-b / a=4 / 3$; лінія $5-b / a=5 / 3$;

$0<t<2 ; a=0,0015 \mathrm{M} ; f=0,3 ; \alpha=\pi / 2, \beta=\pi / 2$

Fig. 4. The dependence of the direction of the body motion on the ratio of amplitudes:

line $1-b / a=1 / 3$; line $2-b / a=2 / 3$; line $3-b / a=1$; line $4-b / a=4 / 3$; line $5-b / a=5 / 3$;

$0<t<2 ; a=0.0015 \mathrm{M} ; f=0.3 ; \alpha=\pi / 2, \beta=\pi / 2$

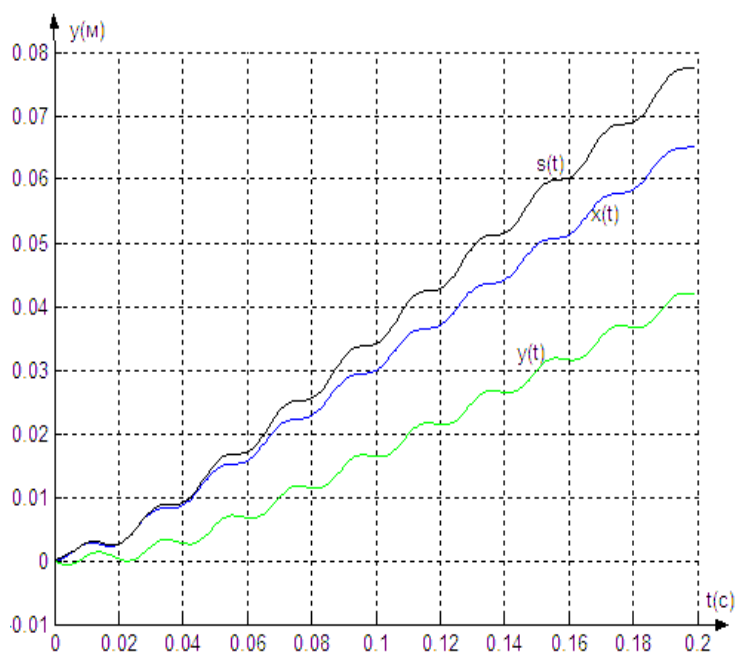

Рис. 6. Зміна в часі координат точки (чи тіла) та відстані $s(t)$ від початку координат:

$\beta=\pi / 8 ; a=b=0,001 \mathrm{~m} ; f=0,3 ; \alpha=\pi / 2$

Fig. 6. Change in time of coordinates of a point (or body) and distance $s(t)$ from origin coordinates: $\beta=\pi / 8 ; a=b=0.001 \mathrm{~m} ; f=0.3 ; \alpha=\pi / 2$ 


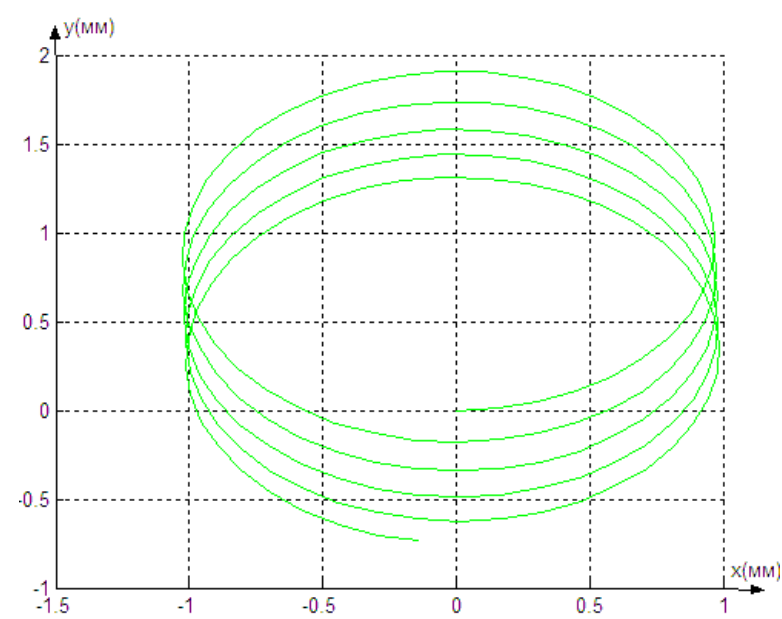

Рис. 7. Траєкторія відносного руху точки поверхні (чи тіла) на початку руху:

за умов $a=b=1 \mathrm{Mм}, c=0, f=0,3$ та зсуву фаз $90^{\circ}$

Fig. 7. The trajectory of the relative motion of a point on the surface (or body) at the beginning of motion: under conditions $a=b=1 \mathrm{~mm}, c=0, f=0.3$ and phase shift $90^{\circ}$

$$
\begin{gathered}
\frac{d^{2} x_{1}}{d t^{2}}=\left(F_{1}(t)-c_{x} x_{1}+T\right) / m_{1} ; \quad \frac{d^{2} x_{2}}{d t^{2}}=-T / m_{2}-\frac{d^{2} x_{1}}{d t^{2}} \\
\frac{d^{2} z_{2}}{d t^{2}}=\left(F_{2}(t)-c_{z} z_{2}\right) /\left(m_{1}+m_{2}\right) \\
N=m_{2} \frac{d^{2} z_{2}}{d t^{2}}+m_{2} g ; T=f N \operatorname{sign}\left(\dot{y}_{2}\right) ; \\
\frac{d^{2} y_{1}}{d t^{2}}=\left(F_{3}(t)-c_{y} y_{1}+T\right) / m_{1} \\
\frac{d^{2} y_{2}}{d t^{2}}=-T / m_{2}-\frac{d^{2} y_{1}}{d t^{2}}
\end{gathered}
$$

де $c_{y}$ - жорсткість пружного елементу під час коливань у напрямку осі $O y$.

$$
F_{3}(t)=\left\{\begin{array}{l}
F_{y} \sin (\omega t+\alpha) ; \\
0
\end{array} \quad F_{1}<0 \quad F_{3}<0 .\right.
$$

2. Можна, навпаки, спочатку переміщати тіло в напрямку осі $O y$, а потім паралельно до осі $O x$, тобто спочатку використовувати рівняння (10), а потім рівняння (9).

Переміщати тіло 2 можна по прямій, яка сполучає початкове i кінцеве положення тіла, тобто одночасно здійснювати коливання у всіх трьох напрямках, але за цієї умови необхідно забезпечити певне співвідношення між амплітудними значеннями сил $F_{1}$ i $F_{3}$, а саме:

$$
\frac{\mathrm{F}_{y}}{\mathrm{E}_{\mathrm{x}}}=\frac{\mathrm{y}_{\mathrm{kk}}-\mathrm{y}_{20}}{\mathrm{x}_{2 \mathrm{k}}-\mathrm{x}_{20}} \text {. }
$$

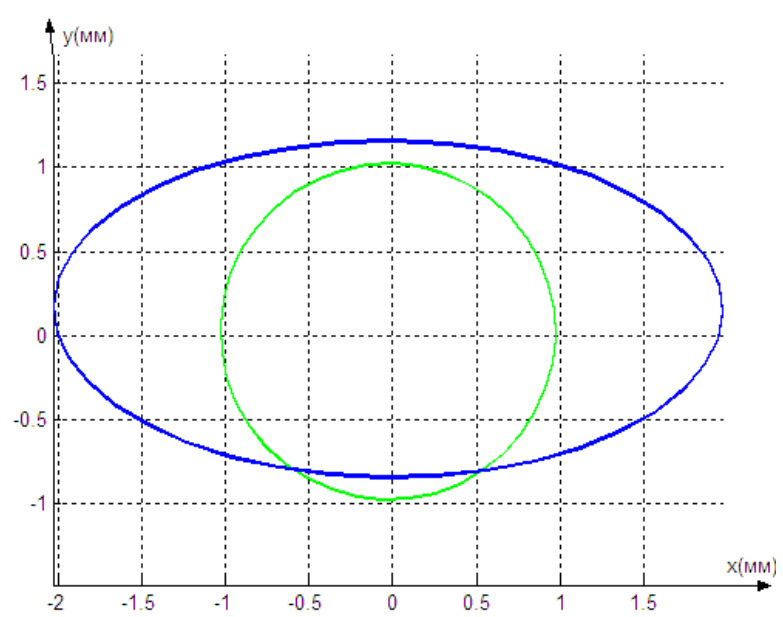

Рис. 8. Траєкторія відносного руху точки при $0,9 c<t<1 c$.

Зсув фаз $90^{\circ}$. Коло відповідає рівним амплітудам $a=b=1 \mathrm{MM}, c=0$.

Еліпс відповідає амплітудам $a=1 \mathrm{Mм}, b=2 \mathrm{Mм}, c=0$ Fig. 8. The trajectory of the relative motion of a point at $0.9 c<t<1 c$.

Phase shift $90^{\circ}$. The circle corresponds to equal amplitudes $a=b=1 \mathrm{~mm}, c=0$.

The ellipse corresponds to the amplitudes

$$
a=1 \mathrm{~mm}, b=2 \mathrm{~mm}, c=0
$$

У цьому разі рух тіла 2 описується системою диференціальних рівнянь, а результати показані на рис. 9-12:

$$
\begin{gathered}
\frac{d^{2} z_{2}}{d t^{2}}=\left(F_{2}(t)-c_{z} z_{2}\right) /\left(m_{1}+m_{2}\right) \\
N=m_{2} \frac{d^{2} z_{2}}{d t^{2}}+m_{2} g ; \quad T_{x}=f N \frac{\dot{x}_{2}}{\sqrt{\dot{x}_{2}^{2}+\dot{y}_{2}^{2}}} ; \\
\frac{d^{2} x_{1}}{d t^{2}}=\left(F_{1}(t)-c_{x} x_{1}+T_{x}\right) / m_{1} ; \frac{d^{2} x_{2}}{d t^{2}}=-T_{x} / m_{2}-\frac{d^{2} x_{1}}{d t^{2}},(12) \\
T_{y}=f N \frac{\dot{y}_{2}}{\sqrt{\dot{x}_{2}^{2}+\dot{y}_{2}^{2}}} ; \\
\frac{d^{2} y_{1}}{d t^{2}}=\left(F_{3}(t)-c_{y} y_{1}+T_{y}\right) / m_{1} ; \quad \frac{d^{2} y_{2}}{d t^{2}}=-T_{y} / m_{2}-\frac{d^{2} y_{1}}{d t^{2}} .
\end{gathered}
$$

Висновки. Запропонований спосіб вібраційного маніпулювання виробами уможливлює його використання під час, наприклад, автоматичного складання, коли необхідно забезпечити правильне суміщення елементів перед їх спряженням і з'єднанням (у вузол). Впровадження аналогічних вібраційних пристроїв у робототехнічні системи значно полегшує та спрощує роботу маніпуляторів. Завдяки їм можна впливати на характер та напрямок руху виробу вібруючою поверхнею. 


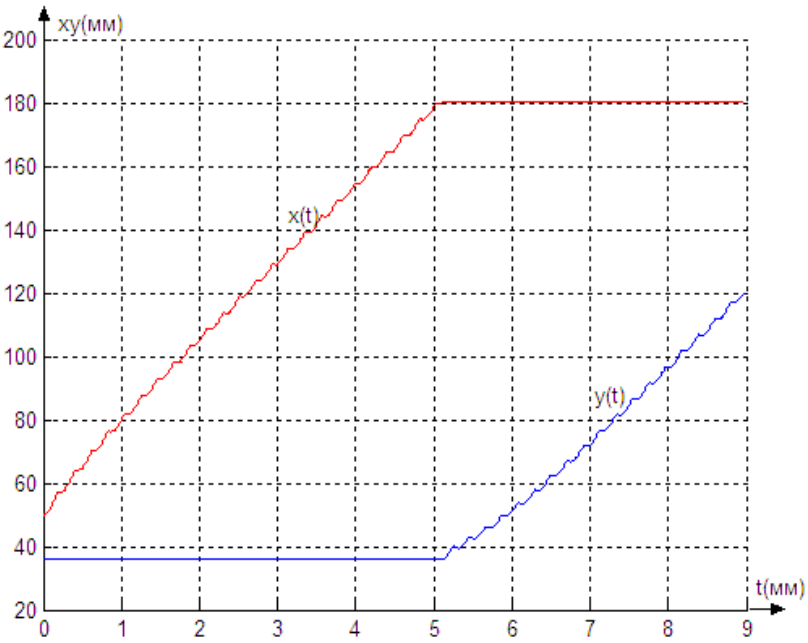

Рис. 9. Графіки переміщення тіла $m_{2}$ відносно напрямків $O x$ та $O y$ від часу $t$

Fig. 9. Graphs of body displacement $m_{2}$ relative to the directions $O x$ and $O y$ from time $t$

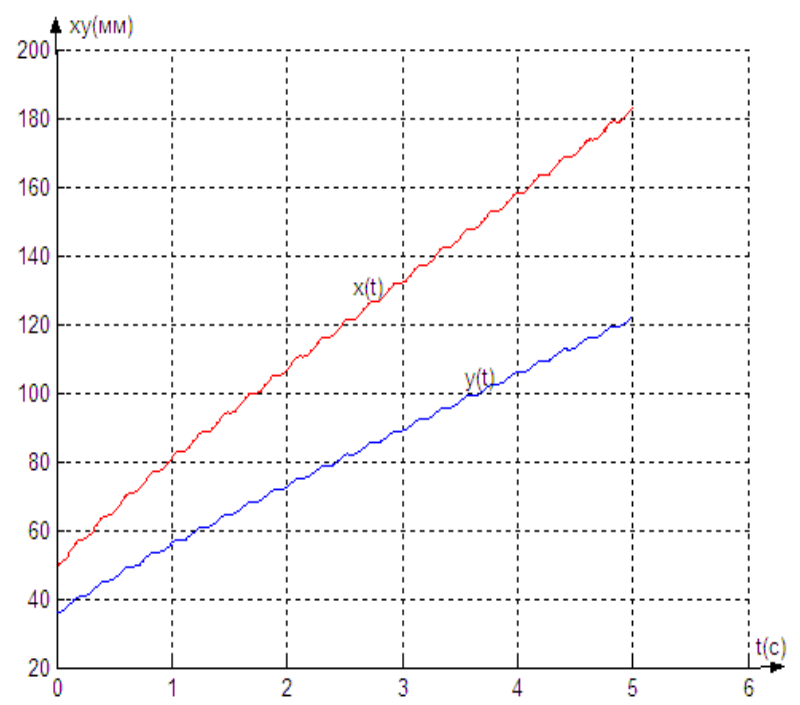

Рис. 11. Графіки зміни координат тіла $m_{2}$ залежно від часу $t$ під час переміщення від початкового до кінцевого положення

Fig. 11. Graphs of changes in body coordinates $m_{2}$ as a function of time $t$ during movement from the initial one to the final position

Одним iз найефективніших впроваджень комбінованого використання вібраційних транспортно-маніпулювальних пристроїв $\epsilon$ технологічна операція щільного укладання виробів, наприклад, під час пакування або ж після вироблення чи оброблення крихких чи маломіцних виробів.

Крім того, використання та розширення функціональних можливостей дозволяє ефективно

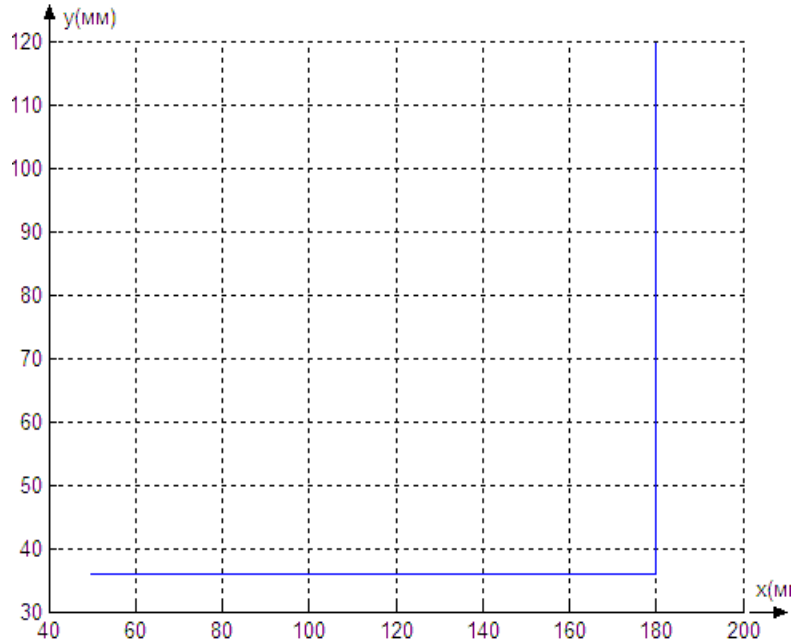

Рис. 10. Траєкторія руху тіла $m_{2}$

Fig. 10. The trajectory of the body $m_{2}$

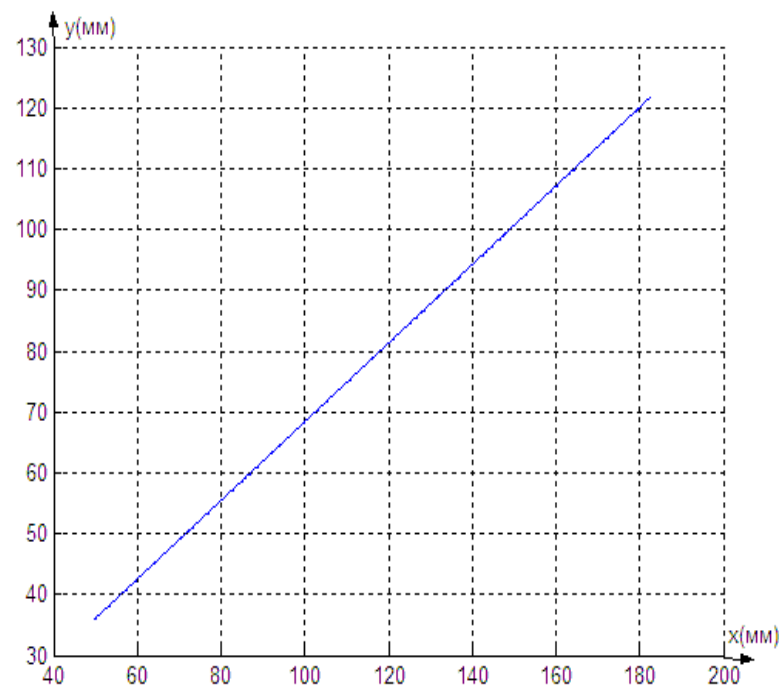

Рис. 12. Траєкторія руху тіла $m_{2}$

Fig. 12. The trajectory of the body $m_{2}$

їх впроваджувати не лише у формування транспортувальних систем автоматичних ліній, а й створити передумови проєктування міжопераційних нагромаджувачів виробів.

\section{Бібліографічний список}

1. Автоматическая загрузка технологических машин: справочник / И. С. Бляхеров и др.; под общ. ред. И. А. Клусова. Москва: Машиностроение, 1990. 400 с. 
2. А. с. 1033393 СССР, В 65 G 27/08. Вибрационный конвейер / В. А. Повидайло. № 3421660/27-03; заяв. 12.04.82; опубл. 07.08.83, Бюл. № 29.

3. А. с. 1033395 СССР, В 65 G 27/32. Вибрационное устройство автоматического группового ориентирования изделий / В. А. Повидайло. № 3423788/27-03; заяв. 12.04.82; опубл. 07.08.83, Бюл. № 29.

4. А. с. 1370027 СССР. Вибрационный конвейер / И. И. Врублевский, В. С. Шенбор. № 4102407/27-03; заяв. 14.08.86; опубл. 30.01.88, Бюл. № 4.

5. А. с. 1586968 СССР. Вибрационный манипулятор / В. А. Щигель, И. И. Врублевский, В. С. Шенбор, Р. В. Якимец. № 4480484/27-03; заяв. 13.09.89; опубл. 23.08.90, Бюл. № 31 .

6. Боровець В., Шенбор В., Боровець І. Міжопераційні вібраційні модулі для транспортування i маніпуляції деталями. Теорія та практика раціонального проектування, виготовлення та експлуатації машинобудівних конструкиій: праці конф. Львів: КІНПАТРІ ЛТД, 2008. C. 209-211.

7. Врублевський I. Й. Вібраційний двомасовий транспортер-маніпулятор 3 незалежними поздовжніми, поперечними та вертикальними коливаннями. Вісник Державного університету “Львівська політехніка”. 1999. № 371. С. 71-74.

8. Врублевський I. Й., Керницький I. С. Розрахунок параметрів просторової коливної системи вібраційної машини з багатокомпонентними коливаннями. Вісник Національного університету “Львівська політехніка”. Оптимізація виробничих процесів $i$ технічний контроль у машинобудуванні і приладобудуванні. 2000. № 412. C. 103-106.

9. Врублевський І. Й., Керницький І. С., Шенбор В. С. Кутова жорсткість двомасового вібраційного транспортера-маніпулятора $з$ трикомпонентними коливаннями. Автоматизація виробничих процесів в машинобудуванні та приладобудуванні. 2000. Вип. 35. С. 67-71.

10. Врублевський I. Й., Пулькевич І. Г., Шенбор В.С. Співвідношення власних частот коливань вібраційного транспортера-маніпулятора 3 багатокомпонентними коливаннями. Вісник Начіонального університету «Львівська політехніка». Автоматизація вироб- ничих проиесів у машинобудуванні та приладобудуванні. 2003. № 37. C. 21-24.

11. Гаврильченко О. В., Шенбор В. С. Вібраційні конвеєри для пакувального обладнання. Упаковка. 2002. № 4. С. 28-29.

12. Иванов А. А. Проектирование систем автоматического манипулирования миниатюрными изделиями. Москва: Машиностроение, 1981. 271 с.

13. Корендій В. М., Гаврильченко О. В., Шенбор В. С. Вібраційні транспортно-маніпулюючі конвеєри для пакувального обладнання. Вісник Національного університету «Львівська політехніка». Оптимізація виробничих процесів $і$ технічний контроль у машинобудуванні та приладобудуванні. 2018. Вип. 891. С. 35-41.

14. Коруняк П. С., Керницький I. С., Ніщенко I. I. Автоматизоване вібраційне маніпулювання виробами та віброманіпулятори / за ред. В. В. Снітинського. Львів: Сполом, 2021. $256 \mathrm{c}$.

15. Повидайло В. А. Гибкие вибрационные модули автоматизированных производств. Автоматизаиия производственных процессов в машиностроении $u$ приборостроении. 1989. Вып. 28. С. 97-101.

16. Повидайло В. А. Принципы создания вибрационных устройств и машин для автоматизированных производств. Вибрации в технике и технологиях. 1994. № 1. С. 18-27.

17. Повидайло В. А., Стоцко 3. А. Метод и экспериментальная установка для определения вероятности западання деталей в гнездо при вибрационной загрузке кассет. Электронная техника. 1973. Сер. 7, вып. 3 (55). C. 53-58.

18. Повидайло В. О. Вібраційні процеси та обладнання. Львів: Вид-во НУ «Львівська політехніка», 2004. 248 c.

19. Щигель В. А., Врублевский И. И. Регулирование кинематики двухмассного виброконвейера с независимыми продольными и нормальными колебаниями. Vibrotechnika. 1991. № 66. Р. 83-89.

20. Vrublevskyi I. Two-Mass Vibratory ConveyorManipulator with Three-Component Electromagnetic Drive. Ukrainian Journal of Mechanical Engineering and Materials Science. 2016. Vol. 2, No. 2. P. 89-98. 